\title{
Agonistic behaviour and control of access to hiding places in two intertidal blennies, Lipophrys pholis and Coryphoblennius galerita (Pisces: Blenniidae)
}

Received: 20 October 2000 / Received in revised form: 29 January 2001 / Accepted: 5 February 2001 / Published online: 20 March 2001 (C) Springer-Verlag and ISPA 2001

\begin{abstract}
In this study we investigated the relationships between dominance rank and access to shelters in captive groups of Lipophrys pholis and Coryphoblennius galerita, as well as the effects of group size and shelter availability. Dominance rank was strongly correlated with size in juvenile $L$. pholis and with sex and size in adult $C$. galerita, males being dominant over females of similar size. Access to shelters was significantly correlated with dominance rank. For both species, most interactions occurred out of shelters. Direct disputes over shelters were always initiated by the dominant fish and the initiator was always the winner. The rate of aggression per fish per unit time decreased with an increase in the number of fish in L. pholis but not in C. galerita. No significant differences were found in groups differing in the number of shelters. C. galerita showed a higher rate of agonistic interactions and a higher proportion of overt aggression than L. pholis. It is suggested that one of the functions of agonistic interactions in these fishes is the control of a set of shelters, in the network of pathways used by each individual within its home range, minimising the time required to hide in case of danger.
\end{abstract}

Keywords Agonistic behaviour - Dominance - Access to shelter $\cdot$ Diffuse territoriality $\cdot$ Intertidal fishes

\section{Introduction}

The presence of agonistic behaviour in rocky intertidal fishes has been a subject of interest for many years but its functional significance is still incompletely understood. Guitel (1893), a pioneering researcher on fish behaviour, first described aggressive behaviour and territo-

Communicated by R. Serrão Santos

C. Faria $(\bullet)$. V. Almada

Unidade de Investigação em Eco-Etologia,

Instituto Superior de Psicologia Aplicada, R. Jardim do Tabaco 34, 1149-041 Lisbon, Portugal

e-mail: cfaria@ispa.pt riality in the breeding males of several intertidal fish species, and Gibson (1968) demonstrated that juveniles of Lipophrys pholis (Linnaeus, 1758) possess a wide repertoire of agonistic behaviour. Other studies have reported the presence of agonistic behaviour in adult males of other species as well as in adult females and juveniles (e.g. Phillips 1977; Wirtz 1978; Almada et al. 1983, 1990; Mayr and Berger 1992; Gonçalves et al. 1996; Faria et al. 1998a). In his successive reviews on the behaviour of littoral fishes, Gibson (1969, 1982, 1986, 1988 , 1999) summarised the available information on the subject.

In many cases, however, it is not fully clear for which resources the fishes are competing. Indeed, although it is known that the males of most intertidal fishes establish breeding territories (Almada and Santos 1995), a situation in which the functional role of agonistic behaviour is probably easy to understand, females and juveniles of many, and possibly most, species are non-territorial (e.g. Fishelson 1963; Almada et al. 1983, 1992, 1994; Santos 1985; Gonçalves and Almada 1998), a condition in which the function of agonistic behaviour is less obvious. In addition, feeding activities are often spread over a wide area covered by water when the tide rises (e.g. Hartley 1949; Gibson 1972; Almada et al. 1992; Gonçalves and Almada 1998), and the periods of lowest activity are at low tide, when the fishes are concentrated in pools and crevices (Gibson 1967, 1970, 1971, 1978). Thus, it remains unclear what adaptive consequences, if any, may result from agonistic behaviour clearly observed in pools at low tide as described by Almada et al. (1983) for Coryphoblennius galerita (Linnaeus, 1758) and L. pholis. Finally, although present in many rocky intertidal fishes, agonistic behaviour seems to be absent in several species that can reach high levels of aggregation without signs of aggression (several examples, mainly in cottids, can be found in Gibson 1982).

Gibson (1968), in the first study of the agonistic behaviour of juveniles of L. pholis, suggested that the fishes presented what he called "diffuse territoriality", that is, instead of defending fixed territories, they could 
defend the priority of access to shelter holes present in their home range, although without controlling exclusive use. Independently, Almada et al. (1983), based on aquarium and field observations, suggested that intertidal blennies, like C. galerita and L. pholis, used a network of familiar pathways that included more than one shelter. In their view, the fishes would compete not for a permanent presence in a shelter, but for undisputed priority of access to the shelters present in the neighbourhood of the location where the fish is at a given moment, to minimise the time during which the fish is exposed if a potential predator appears in the area. This hypothesis was based on three types of observations:

1. In tide pools, fishes disturbed by the observer often followed the same pathways.

2. In their attempts to escape, fishes entered holes that had been occupied by other fishes and one of them was forced out.

3. When undisturbed, fishes were often seen in conspicuous positions, in salient topographic features of the pools, but upon disturbance they dashed to shelters in a multiplicity of distinct directions, as if each individual "knew" the shortest route to escape, leaving the observer unable to track their diverse movements.

Other studies of rock intertidal fishes that provide evidence that access to shelter is an important resource at stake in agonistic encounters are those of Grossman (1980), Behrents (1987), Koppel (1988), and Mayr and Berger (1992). Faria et al. (1998b) partly tested this hypothesis, demonstrating that there is a significant correlation between the dominance rank of each fish in a group and the time spent in shelters. This correlation was true for C. galerita and L. pholis, but not for Gobius cobitis (Pallas, 1814), another intertidal fish that lives in a habitat poor in shelters like crevices and small holes suitable for single fishes.

In this article we further investigate the hypothesis that access to shelter sites is rank dependent and controlled by agonistic interactions, based on observations of captive groups of $L$. pholis and $C$. galerita in tanks where group size and shelter availability were manipulated. To address this issue, we considered that it would be necessary to study in more detail the character of the dominance orders in the groups of each species and the possible relationships between dominance and spatial distribution of fishes outside shelters.

\section{Methods}

From October 1997 to May 1999, 32 groups of L. pholis and C. galerita were observed in tanks of $118 \times 28 \times 27 \mathrm{~cm}$. The tanks were illuminated $10 \mathrm{~h}$ per day and were equipped with biological filters. The temperature was $17^{\circ} \mathrm{C}$. Fishes were fed with pieces of common cockle. A total of $224 \mathrm{~h}$ of observation was made of the 32 groups, 16 of $C$. galerita and 16 of L. pholis. The observations were based on groups of six fishes (8 groups of each species) and four fishes (8 groups of each species), the fishes being 3-7 cm total length (TL). This size range was chosen to use fishes of comparable size. Because in this size range $L$. pholis are almost always juveniles and $C$. galerita tend to be adults, individuals of $C$. galerita with signs of being in reproductive condition were not used. For each species group and density (six or four fishes), half of the tanks were provided with two shelters (stones covered with algae) and half with four shelters. Each group stayed in captivity for periods of 17 days, but no observations were made in the first 7 days (habituation period). On subsequent days, daily observations were made on 7 of the 10 remaining days, $1 \mathrm{~h}$ per day, randomly distributed from 0900 hours to 1900 hours. The habituation period of a week was chosen since in previous studies (Almada et al. 1983; Faria et al. 1998b), it was found that after 7 days the fishes moved actively and interacted frequently with each other. We assumed that these findings were indicators of habituation to the conditions of captivity. In addition, a week is supposed to be a period sufficiently long to minimise the influence of the tidal rhythm that these fishes show in nature (Gibson 1967).

The fishes were recognised individually by their relative size and the peculiarities of their colour patterns. For each fish, its location in the tank was noted every 10 min during the observation time (six scans per hour). The sequences of agonistic behaviour that occurred during each hour of observation were recorded. A fish was classified as the loser of an encounter if at the end of the interaction it withdrew or fled from the opponent, or was threatened or attacked without retaliation. When both fishes withdrew without an apparent asymmetry, the outcome was classified as inconclusive. To make data from different groups comparable, the size (TL) of each fish was expressed as relative size in relation to the other members of the group. To calculate the dominance rank of each fish in its group we followed the procedure described in Appleby (1983). This calculation involves the computation of all the interactions for each possible pair of individuals in a group. If a member of the pair wins the majority of the interactions in which the pair was involved, it is assigned a score of $(+1)$; the loser of most interactions is assigned a score of (0); if both members of the pair were winners the same number of times, they are both assigned a score of (0.5). The scores of each individual are subsequently summed and individuals are finally ordered according to their respective sum of scores. To analyse the spatial distribution of agonistic encounters the bottom of the tank was divided by an imaginary grid of $3 \times 2$ cells.

Statistical analysis was performed using the computer program Statistica for Windows (v. 4.5, C. Statsoft Inc., 1993). The analysis of contingency tables was performed using the simulation statistical procedure ACTUS (Estabrook and Estabrook 1989), and the $\chi^{2}$ goodness-of-fit test was performed using the simulation procedure Adersim (see Almada and Oliveira 1997 for details). Both ACTUS and Adersim compare the observed values with a number of sets (usually a thousand) of simulated values randomly generated, with probabilities proportional to the expected value of each cell of the data set. These techniques have the advantage of circumventing the limitations associated with the use of the chisquare distribution, allowing at the same time the assessment of the significance of the individual cells of the data set.

The relationships between sex and rank and between size and rank were analysed as described in Faria et al. (1998b). As this procedure raises some peculiar problems it will be described in some detail. These relationships were assessed using Spearman correlations between relative size and rank and between sex and rank, computed separately for each group. This raises some difficulties: first, calculating correlations would not be the method of choice to test relationships with dichotomous variables like sex; second, the data are used twice to study the relationships of rank with sex and size; and finally, with groups of small size, such as six or four, only extreme values of correlations are significant. The procedure is thus of low sensitivity. We decided to adopt it because, despite all these disadvantages, it has the advantage of preserving the inter-group variability, allowing at the same time the comparison of the associations of rank with sex and size with the same statistic, in a situation in which more standard tests, such as analysis of variance (ANOVA), would also be questionable. In doing so we must stress, however, that it is not the statistical results for each group that are relevant, but the repeated occurrence of the same patterns across groups. 
Table 1 Correlation between relative size or sex ( 1 for male and 2 for female) of each fish and its rank in the hierarchies observed

\begin{tabular}{|c|c|c|c|c|c|c|c|c|}
\hline \multirow[t]{3}{*}{ Group } & \multicolumn{4}{|c|}{ Lipophrys pholis } & \multicolumn{4}{|c|}{ Coryphoblennius galerita } \\
\hline & \multicolumn{2}{|l|}{ Size } & \multicolumn{2}{|l|}{ Sex } & \multicolumn{2}{|l|}{ Size } & \multicolumn{2}{|l|}{ Sex } \\
\hline & $r_{\mathrm{s}}$ & $P$ & $r_{\mathrm{s}}$ & $P$ & $r_{\mathrm{s}}$ & $P$ & $r_{\mathrm{s}}$ & $P$ \\
\hline 6 fishes $/ 2$ shelters & 1.00 & $<0.001$ & -0.31 & NS & 1.00 & $<0.001$ & -0.62 & NS \\
\hline 6 fishes $/ 2$ shelters & 0.90 & $<0.05$ & -0.08 & NS & 0.90 & $<0.05$ & -0.00 & NS \\
\hline 6 fishes $/ 2$ shelters & 1.00 & $<0.001$ & -0.67 & NS & 0.38 & NS & -0.83 & $<0.05$ \\
\hline 6 fishes $/ 2$ shelters & 1.00 & $<0.001$ & -0.72 & NS & 0.78 & NS & -0.88 & $<0.05$ \\
\hline 6 fishes $/ 4$ shelters & 0.94 & $<0.01$ & -0.33 & NS & 0.94 & $<0.01$ & -0.46 & NS \\
\hline 6 fishes $/ 4$ shelters & 0.90 & $<0.05$ & -0.63 & NS & 0.46 & NS & -0.88 & $<0.05$ \\
\hline 6 fishes $/ 4$ shelters & 1.00 & $<0.001$ & -0.31 & NS & 0.71 & NS & -0.83 & $<0.05$ \\
\hline 6 fishes $/ 4$ shelters & 1.00 & $<0.001$ & -0.60 & NS & 0.90 & $<0.05$ & -0.29 & NS \\
\hline 4 fishes $/ 2$ shelters & 0.95 & NS & -0.06 & NS & 0.63 & NS & 0.00 & NS \\
\hline 4 fishes $/ 2$ shelters & 1.00 & $<0.001$ & -0.32 & NS & 0.63 & NS & -0.54 & NS \\
\hline 4 fishes $/ 2$ shelters & 1.00 & $<0.001$ & 0.00 & NS & 0.95 & NS & -0.24 & NS \\
\hline 4 fishes $/ 2$ shelters & 1.00 & $<0.001$ & -0.63 & NS & 0.40 & NS & 0.00 & NS \\
\hline 4 fishes $/ 4$ shelters & 0.95 & NS & -0.06 & NS & 0.80 & NS & 0.89 & NS \\
\hline 4 fishes $/ 4$ shelters & 1.00 & $<0.001$ & -0.32 & NS & 0.95 & NS & 0.00 & NS \\
\hline 4 fishes $/ 4$ shelters & 0.95 & NS & -0.82 & NS & 0.95 & NS & 0.45 & NS \\
\hline 4 fishes/4 shelters & 1.00 & $<0.001$ & -0.26 & NS & 0.32 & NS & 0.26 & NS \\
\hline
\end{tabular}

To study the relationship between rank and spatial distribution of fishes outside shelters, they were divided in two rank categories, the three higher and the three lower in the groups of six fishes and the two higher and the two lower in the groups of four fishes. This classification was used to test the hypothesis that fishes of the higher ranks would be less frequently in close proximity to other fishes than fishes of lower ranks.

\section{Results}

\section{Order of dominance}

For L. pholis there were highly significant positive correlations between size and rank, for all the groups of six fishes and even for most groups of four fishes, despite the small number of individuals (Table 1). L. pholis only attains sexual maturity when more than 6-7 cm TL (Faria et al. 1996), the upper size limits of the fishes in this study. Thus, most or all of our subjects were juveniles. For $C$. galerita the correlation coefficients of rank with size and sex varied markedly from group to group, with some groups yielding significant results for size and others for sex, males being dominant over females (Table 1). Although it is not shown in the table, when in some groups some females were sufficiently larger than males, they were dominant over them; thus the emerging picture is one in which at similar sizes, males are dominant over females, although sufficiently larger females can be dominant over males. In $C$. galerita, sexual maturity is attained at about 3-4 cm TL (Fives 1980), so the fish used in this study were probably adults in most cases.

There is also a very significant positive correlation between rank and an index of success in agonistic encounters (ISAE), consisting of the number of victories of an individual over the total number of interactions in which that individual was involved. This was true for both $L$. pholis and C. galerita. For both species, this correlation coefficient ranged from $r_{\mathrm{s}}=0.95(n=6)$ to $r_{\mathrm{s}}=1.0$
Table 2 Results of nested ANOVA, testing the effect of number of fish, number of shelters, rank, and group on number of interactions

\begin{tabular}{|c|c|c|c|c|c|c|}
\hline \multirow{2}{*}{$\begin{array}{l}\text { Group } \\
2\end{array}$} & \multicolumn{3}{|c|}{ L. pholis } & \multicolumn{3}{|c|}{ C. galerita } \\
\hline & $d f$ & $F$ & $P$ & $d f$ & $F$ & $P$ \\
\hline Number of fish & 1 & 34.280 & $<0.001$ & 1 & 1.259 & NS \\
\hline Number of shelters & 1 & 24.550 & $<0.001$ & 1 & 0.116 & NS \\
\hline Rank & 1 & 31.596 & $<0.001$ & 1 & 6.968 & $<0.05$ \\
\hline Group & 24 & 3.780 & $<0.001$ & 24 & 2.189 & $<0.05$ \\
\hline
\end{tabular}

Table 3 Results of nested ANOVA, testing the effect of species, number of fish, number of shelters, rank, and group on number of interactions

\begin{tabular}{lrrl}
\hline Source & $d f$ & \multicolumn{1}{l}{$F$} & $P$ \\
\hline Species & 1 & 54.530 & $<0.001$ \\
Number of fish & 1 & 7.240 & $<0.01$ \\
Number of shelter & 1 & 1.224 & NS \\
Rank & 1 & 16.465 & $<0.001$ \\
Group & 24 & 2.429 & $<0.001$ \\
\hline
\end{tabular}

$(n=4)$, with the corresponding significance levels ranging from $P<0.01$ to $P<0.001$.

Finally, for both species, fishes of higher ranks took part in more interactions than fishes of lower ranks (Table 2). There are, however, important differences between the two species. C. galerita showed a significantly higher number of interactions for the same observation time than $L$. pholis (Table 3 ). In addition, the interactions of $C$. galerita involved a significantly higher proportion of overt aggression (charging plus chasing plus butting plus biting plus nodding over all the agonistic behaviour patterns observed) than $L$. pholis (Tables 4, 5) (see Gibson 1968 and Almada et al. 1990 for descriptions). 
Table 4 Statistical analysis of the agonistic behaviours of each species, using ACTUS, where the observed values did not exceed the simulated values. $\chi^{2}=1575.37, d f=11, P<0.001$. The results are based on the comparison of observed values with 1,000 simulated tables. $A D$ advancing; $T H$ threatening; $C H$ charging; $B U$ butting; $N O$ nodding; $B I$ biting; $C H S$ chasing; $P U S$ pushing; $H T$ head turning; $S U$ submission; $A W$ moving away; $F L$ fleeing

\begin{tabular}{lllllllllllll}
\hline Species & $\mathrm{AD}$ & $\mathrm{TH}$ & $\mathrm{CH}$ & $\mathrm{BU}$ & $\mathrm{NO}$ & $\mathrm{BI}$ & $\mathrm{CHS}$ & $\mathrm{PUS}$ & $\mathrm{HT}$ & $\mathrm{SU}$ & AW & FL \\
\hline L. pholis & 492 & $0 * * *$ & 1000 & 1000 & 1000 & 998 & 1000 & $0 * * *$ & $0 * * *$ & 1000 & $0 * * *$ & 528 \\
C. galerita & 529 & 1000 & $0 * * *$ & $0 * * *$ & $0 * * *$ & $21 *$ & $1 * *$ & 1000 & 1000 & $0 * * *$ & 1000 & 479 \\
\hline
\end{tabular}

$* P<0.05 ; * * P<0.01 ; * * * P<0.001$ (one-tailed)

Table 5 Statistical analysis of the agonistic behaviours of each species, as in Table 4, but where the simulated values did not exceed the observed values.

\begin{tabular}{lllllllllllll}
\hline Species & $\mathrm{AD}$ & $\mathrm{TH}$ & $\mathrm{CH}$ & $\mathrm{BU}$ & $\mathrm{NO}$ & $\mathrm{BI}$ & $\mathrm{CHS}$ & $\mathrm{PUS}$ & $\mathrm{HT}$ & SU & AW & FL \\
\hline L. pholis & 520 & 1000 & $0 * * *$ & $0 * * *$ & $0 * * *$ & $2 * *$ & $0 * * *$ & 1000 & 1000 & $0 * * *$ & 1000 & 480 \\
C. galerita & 480 & $0 * * *$ & 1000 & 1000 & 1000 & 980 & 999 & $0 * * *$ & $0 * * *$ & 1000 & $0 * * *$ & 527 \\
\hline
\end{tabular}

$* P<0.05 ; * * P<0.01 ; * * * P<0.001$ (one-tailed)

Table 6 Correlation between the time spent in shelters of each fish and index of success in agonistic encounters

\begin{tabular}{llllll}
\hline Group & \multicolumn{2}{l}{ L. pholis } & & \multicolumn{2}{l}{ C. galerita } \\
\cline { 2 - 3 } \cline { 6 - 7 } & $r_{\mathrm{s}}$ & $P$ & & $r_{\mathrm{s}}$ & $P$ \\
\hline 6 fishes/2 shelters & 0.83 & $<0.05$ & & 0.83 & $<0.05$ \\
6 fishes/2 shelters & 0.83 & $<0.05$ & & 0.83 & $<0.05$ \\
6 fishes/2 shelters & 0.88 & $<0.05$ & & 0.86 & $<0.05$ \\
6 fishes/2 shelters & 0.94 & $<0.01$ & & 0.90 & $<0.05$ \\
6 fishes/4 shelters & 0.83 & $<0.05$ & & 0.90 & $<0.05$ \\
6 fishes/4 shelters & 0.83 & $<0.05$ & & 0.68 & $<0.05$ \\
6 fishes/4 shelters & 0.06 & NS & & 0.76 & $<0.05$ \\
6 fishes/4 shelters & 0.68 & $<0.05$ & & 0.99 & $<0.001$ \\
4 fishes/2 shelters & 0.54 & NS & & 1.00 & $<0.001$ \\
4 fishes/2 shelters & 0.40 & NS & & 1.00 & $<0.001$ \\
4 fishes/2 shelters & 0.26 & NS & & 0.32 & NS \\
4 fishes/2 shelters & 0.78 & NS & & 0.74 & NS \\
4 fishes/4 shelters & 0.27 & NS & & 1.00 & $<0.001$ \\
4 fishes/4 shelters & 0.32 & NS & & 0.32 & NS \\
4 fishes/4 shelters & 0.96 & $<0.05$ & & 1.00 & $<0.001$ \\
4 fishes/4 shelters & 0.26 & NS & & 0.60 & NS \\
\hline
\end{tabular}

Social rank and access to shelter

All groups of six fishes of $C$. galerita and seven of the eight groups of six fishes of L. pholis showed significant positive correlations between the ISAE and the percentage of time spent in shelters (Table 6). Even some of the groups of four fishes showed significant positive correlations between these variables, a remarkable finding since for $n=4$ only extremely high correlation coefficients are significant. In addition, fishes of lower rank are more frequently dislodged from shelters than dominant ones, a result that holds for both $L$. pholis and $C$. galerita (Table 7). These results provide additional confirmation of the findings of Faria et al. (1998b), that dominant fishes have priority of access to shelters.

It seems likely that during its membership in a group, each individual acquires some information on which shelters it could invade, and/or over which individuals it
Table 7 Results of nested ANOVA, testing the effect of number of fish, number of shelters, rank, and group on dislodgement

\begin{tabular}{lrlllllll}
\hline Source & \multicolumn{3}{l}{ L. pholis } & & \multicolumn{3}{l}{ C. galerita } \\
\cline { 2 - 3 } \cline { 6 - 8 } & $d f$ & $F$ & $P$ & & $d f$ & $F$ & \multicolumn{2}{l}{$P$} \\
\hline Number of fish & 1 & 15.363 & $<0.001$ & & 1 & 13.274 & $<0.001$ \\
Number of shelters & 1 & 3.444 & NS & & 1 & 0.025 & NS \\
Rank & 1 & 8.731 & $<0.01$ & & 1 & 9.580 & $<0.01$ \\
Group & 24 & 1.787 & NS & & 24 & 0.532 & NS \\
\hline
\end{tabular}

is dominant. This conclusion is supported by the finding that in 148 encounters in shelters for L. pholis and 493 encounters in shelters for $C$. galerita, the intruder always won.

It is important to note, however, that most interactions occurred out of the shelters (96\% for both species) and that the fishes spent most of the time out of shelters (88\% in the case of L. pholis and $84 \%$ in the case of C. galerita). The access of fishes to shelters was not exclusive, and although the sites preferred by dominant fishes were less frequently visited by others, even the dominant animals did not usually control those shelters for all of the time, and other fishes would use them when dominants were absent, being dislodged when dominants visited them (Fig. 1). At the same time, the fishes did not limit their right of access to a single shelter, dislodging subordinate fishes in shelters in parts of the tank that they visited less frequently (Table 8).

To control for a possible difference in the character of the agonistic interactions that took place in direct disputes over shelters and those that took place in the open, we computed ranks using only data of the interactions that occurred outside shelters. These were in complete agreement with ranks computed when interactions in shelters were also considered. Thus there is firm evidence that the fishes were not fighting for permanent occupation of shelters, but rather the rank they attained 
Table 8 Number of shelters visited by first ranks of each group (three for groups of six fishes and two for groups of four fishes)

\begin{tabular}{|c|c|c|c|c|c|c|}
\hline \multirow[t]{2}{*}{ Group } & \multicolumn{3}{|c|}{ L. pholis } & \multicolumn{3}{|c|}{ C. galerita } \\
\hline & Rank 1 & Rank 2 & Rank 3 & Rank 1 & Rank 2 & Rank 3 \\
\hline 6 fishes $/ 2$ shelters & 2 & 2 & 2 & 2 & 2 & 2 \\
\hline 6 fishes $/ 2$ shelters & 2 & 2 & 2 & 2 & 1 & 2 \\
\hline 6 fishes $/ 2$ shelters & 2 & 2 & 1 & 2 & 2 & 1 \\
\hline 6 fishes $/ 2$ shelters & 2 & 2 & 2 & 2 & 2 & 2 \\
\hline 6 fishes $/ 4$ shelters & 1 & 1 & 3 & 4 & 2 & 4 \\
\hline 6 fishes $/ 4$ shelters & 2 & 2 & 2 & 3 & 1 & 2 \\
\hline 6 fishes $/ 4$ shelters & 1 & 0 & 1 & 2 & 3 & 1 \\
\hline 6 fishes $/ 4$ shelters & 3 & 1 & 0 & 2 & 3 & 2 \\
\hline 4 fishes $/ 2$ shelters & 0 & 0 & - & 2 & 2 & - \\
\hline 4 fishes $/ 2$ shelters & 1 & 0 & - & 2 & 2 & - \\
\hline 4 fishes $/ 2$ shelters & 0 & 1 & - & 2 & 1 & - \\
\hline 4 fishes/ 2 shelters & 1 & 0 & - & 2 & 2 & - \\
\hline 4 fishes/4 shelters & 0 & 1 & - & 3 & 3 & - \\
\hline 4 fishes $/ 4$ shelters & 2 & 0 & - & 1 & 3 & - \\
\hline 4 fishes $/ 4$ shelters & 2 & 2 & - & 3 & 4 & - \\
\hline 4 fishes $/ 4$ shelters & 0 & 2 & - & 1 & 2 & - \\
\hline
\end{tabular}
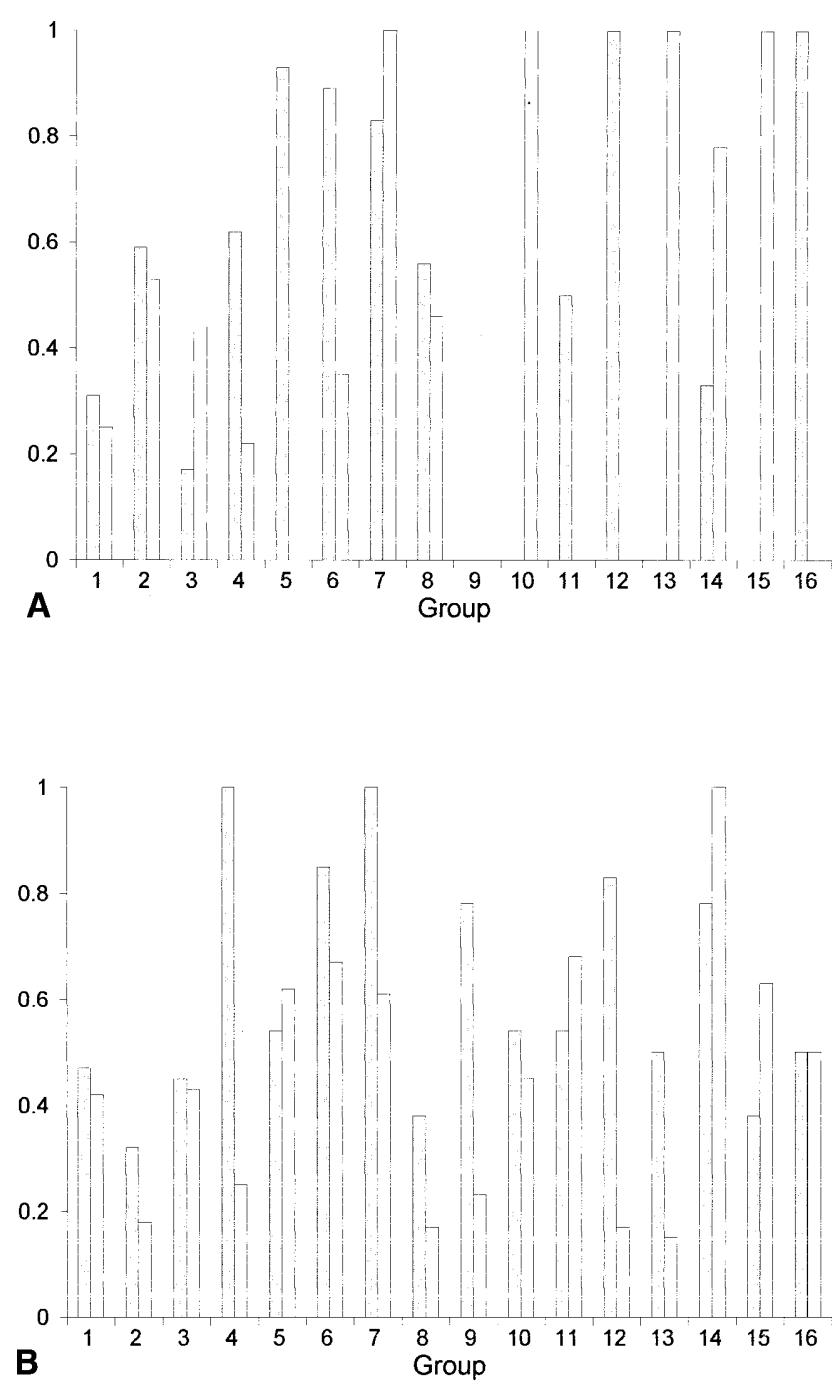

Fig. 1A, B Number of scans occupied by dominant fishes, rank 1 (grey bars) and rank 2 (white bars), over total number of scans in which each shelter was occupied. A Lipophrys pholis; B Coryphoblennius galerita through their interactions controlled their right of priority of access to shelters.

Finally, when the effects of number of fishes and availability of shelters were considered, the following conclusions emerged:

1. The number of dislodgements to which each individual was subjected was significantly higher in groups of six fishes than in groups of four fishes, both for L. pholis and C. galerita (Table 7). This provides additional, albeit indirect evidence of competition for shelters. No significant differences were found in the number of dislodgements that occurred at the two levels of shelter availability used in this study (Table 7).

2. Regarding the number of interactions, $C$. galerita did not reveal significant differences in the number of agonistic interactions per fish with group size or shelter availability (Table 2). Surprisingly, an increase in the number of $L$. pholis from four to six fishes and/or a decrease of the number of shelters from four to two caused a decrease in the number of interactions per fish, contrary to our expectations (Table 2).

Dominance and spatial distribution of fishes outside shelters

The strong relationship between rank and access to shelters demonstrated above led us to investigate the extent to which rank affects the spatial distribution outside shelters. For C. galerita, the fish of higher rank are less frequently found with another fish in the same cell of the imaginary grid that divided the bottom of the tank than is the case with subordinates (Table 9), thus confirming our hypothesis. For L. pholis, however, no significant differences were found.

When the observed interactions were compared with those expected if fishes of all social categories interacted with each other with the same probability, it is apparent that for $C$. galerita fish of higher rank and males interact 
Table 9 Results of nested ANOVA, testing the effect of species, number of fish, number of shelters, rank, and group on number of scans with other fish in the same cell

\begin{tabular}{lrrl}
\hline Source & $d f$ & $F$ & $P$ \\
\hline Species & 1 & 161.869 & $<0.001$ \\
Number of fish & 1 & 64.922 & $<0.001$ \\
Number of shelters & 1 & 4.769 & $<0.05$ \\
Rank & 1 & 6.343 & $<0.05$ \\
Group & 24 & 5.347 & $<0.001$ \\
\hline
\end{tabular}

with each other less frequently than would be expected by chance (Statistical analysis using the $\chi^{2}$ goodnessof-fit-test Adersim revealed that for comparisons between ranks, all groups of six fishes and three of the eight groups of four fishes show significant differences between the observed and expected values, with minimum $\chi^{2}=6.62, d f=2, P<0.05$ and maximum $\chi^{2}=23.69$, $d f=2, P<0.001$ for groups of six fishes, and minimum $\chi^{2}=9.09, d f=2, P<0.05$ and maximum $\chi^{2}=27.66, d f=2$, $P<0.001$ for groups of four fishes; for comparisons between sex categories, four of the eight groups of six fishes showed significant differences between observed and expected values, with minimum $\chi^{2}=6.44, d f=2$, $P<0.05$ and maximum $\chi^{2}=30.28, d f=2, P<0.001$ ). As males tend to be dominant over females, these effects of rank and sex are unlikely to be independent of each other. For $L$. pholis, no significant differences were found between observed and expected values. Thus, the available evidence supports the conclusion that dominant C. galerita tend to space themselves and avoid interacting with each other, a phenomenon that was not apparent for L. pholis.

\section{Discussion}

The results presented above provide multiple lines of evidence in favour of the hypothesis that for both the species studied, dominance controls access to shelters. Indeed, the results of this study strongly confirm the findings of Faria et al. (1998b) of a strong positive correlation between rank and access to shelters. In addition, we could show that dominants effectively dislodge subordinates from shelters, and when the number of fishes per tank increased the number of dislodgements also increased. Further tests of this hypothesis will require experimental manipulation of the rank of individual fishes to see if their access to shelters changes accordingly, and field work to investigate the extent to which the findings obtained in the laboratory are applicable in nature.

The circumstantial evidence available on this topic has been cited in the Introduction and indicates that during their movements in the tide pools, individual fishes tend to follow a network of specific pathways, and when disturbed escaped to specific shelters. Almada et al. (1983) also report that some individuals in the process of escaping from disturbance caused by the observer sometimes lost time when trying to enter a shelter hole that was already occupied. In this situation an agonistic encounter typically took place and one of the fishes was expelled from the hole. The same authors stated that when holes were artificially obstructed, some individuals that were trying to escape repeatedly probed the pieces of cotton used to block the entrances of holes, as if "expecting to find them open" (Almada et al. 1983).

These observations, coupled with the finding that fishes removed from their pools and released several meters away were found in their original pool the next day (Almada et al. 1983, see also Santos 1986 for Parablennius sanguinolentus), support the hypothesis that when in pools, fishes acquire information on the locations of shelters and their relative ability to control them when they need to escape. Thus, our results are consistent with the limited evidence available on the behaviour of these species in nature.

The finding that the great majority of agonistic interactions took place out of shelters and the undisputed ability of dominants to dislodge subordinates are both consistent with the above interpretation that fishes would fight for access to shelters when undisturbed. In so doing, they would avoid both wasting time and the risk of becoming conspicuous, situations that could result if they only disputed the use of shelters when in urgent need of refuge.

In the present study even dominant fishes did not restrict their visits to a single shelter, and when they were vacated, shelters could be temporarily occupied by subordinate individuals. This finding agrees with the idea of a "diffuse territoriality" as proposed by Gibson (1968) and Almada et al. (1983), in which fishes would not defend a single shelter, but rather a network of familiar holes scattered in their home ranges. This situation would give dominants the advantage of a quicker undisputed access to nearby shelters, in the part of the home ranges where they happen to be when disturbed, thus minimising the time they remain exposed, as proposed by Almada et al. (1983).

In the case of the breeding males, this "diffuse territoriality" would change to a more traditional form of territorial defence, because the males tend to concentrate their visits on a single hole and restrict their movements to the surroundings of that hole (e.g. Qasim 1956; Almada et al. 1983, 1990; Almada and Santos 1995). Our finding that in C. galerita, males were dominant over females of similar size and thus had greater access to shelter, although they were not in breeding condition, may represent an intermediate stage between the two extreme types of territoriality. The absence of an effect of sex in L. pholis is probably trivial, since we were basically dealing with juveniles.

The lack of significant differences between groups with two and four shelters may have been caused by the small size of the difference in the number of shelters used. In groups of six fishes shelters are in short supply when four are provided, and if some dominant fishes control several shelters, the numbers used could have been too low in both circumstances. 
Although the overall patterns were basically similar in the two species studied, some important differences were apparent. L. pholis performed a lower proportion of overt aggression than $C$. galerita and had a lower rate of agonistic interactions per unit time. They also failed to reveal an active spacing of individuals close in rank, when out of shelters, which was marked in $C$. galerita. Finally, the rates of aggression per fish per unit time decreased in L. pholis when the group size increased, a condition not shown by $C$. galerita. It would be interesting to test in the future the hypothesis that these differences are biologically meaningful and represent real differences between the ways the two species use their habitats. C. galerita usually settle in pools with a very complex topography and remain in this type of pool when adults, except for some males that leave them temporarily to establish nests in small holes and crevices of the rocks. Adult $C$. galerita remain small fish, individuals larger than $8 \mathrm{~cm}$ being rare (Fives 1980; Faria and Almada 2001), and they are almost never seen in aggregations (unpublished). L. pholis recruit to a wider variety of substratum types, many juveniles occurring in shallow pools of simpler topography. When they reach $7-8 \mathrm{~cm}$ in length they tend to leave the pools. They begin to seek larger crevices, spaces under stones, and other protected microhabitats in which to spend the low tide, often in aggregations of more than ten individuals that may stay almost motionless with the bodies in close contact (Qasim 1957; Faria and Almada 2001). The adults of $L$. pholis are much larger than $C$. galerita; some individuals may reach about $20 \mathrm{~cm}$ (Zander 1986; even more in one population, R.S. Santos, Personnal communication).

A quantitative study of the size distribution of holes on the rock surfaces is lacking. It was very apparent to us, however, during several years of field work, that many more interstices and tube-like holes with sizes suitable for the sheltering of individual small fish were available than holes fitting the bodies of larger fish (e.g. more than $15 \mathrm{~cm}$ ). The causes of these differences are unknown to us. They may have to do with size limitations of rock-drilling organisms like endolithic bivalves, or with the mechanisms of the rock erosion on the platform.

We suggest that for $C$. galerita the defence of the small crevices that they use as hiding places, which often tightly fit the body of a single fish, will be much more decisive for the survival of the fish, as already noted by Kotrschal (1988) for other small blennies in the Adriatic, than it would be for the larger L. pholis, for which hiding places suitable for the body of single fish are usually unavailable in nature. This would explain why the evolution of $L$. pholis may have favoured individuals, both dominants and subordinates, that in some circumstances were able to limit or suppress their aggression, allowing them to use collective shelters and avoid the costs of unprofitable aggression over hiding places, the exclusive defence of which would confer little or no advantage.
Acknowledgements Part of this study was supported by Fundação para a Ciência e Tecnologia (FCT) as part of the PRAXIS XXI/3/3.2/EMG/1957/95 and Pluriannual Program (UI\&D 331/94) projects. C.F. was also supported by a grant from FCT (PRAXIS XXI/BD/5666/95). We would like to thank V. Carvalho for help in the maintenance of the aquarium and $\mathrm{J}$. Robalo, who revised the English.

\section{References}

Almada VC, Oliveira RF (1997) Sobre o uso de estatística de simulação em estudos de comportamento. Análise Psicol 15:97-109

Almada VC, Santos RS (1995) Parental care in the rocky littoral: adaptation and exaptation in Atlantic and Mediterranean blennies. Rev Fish Biol Fish 5:23-37

Almada VC, Dores J, Pinheiro A, Pinheiro M, Santos RS (1983) Contribuição para o estudo do comportamento de Coryphoblennius galerita (L.) (Pisces; Blenniidae). Mem Museu Mar, Série Zool 2(24):1-165

Almada VC, Oliveira RF de, Barata EN, Gonçalves EJ, Rito AP (1990) Field observations on the behaviour of the breeding males of Lipophrys pholis (Pisces: Blenniidae). Port Zool $1: 27-36$

Almada VC, Gonçalves EJ, Oliveira RF de, Barata EN (1992) Some features of the territories in the breeding males of the intertidal blenny Lipophrys pholis (Pisces: Blenniidae). J Mar Biol Assoc UK 72:187-197

Almada VC, Gonçalves EJ, Santos AJ, Baptista C (1994) Breeding ecology and nest aggregations in a population of Salaria pavo (Pisces: Blenniidae) in an area where nest sites are very scarce. J Fish Biol 45:819-830

Appleby MC (1983) The probability of linearity in hierarchies. Anim Behav 31:600-608

Behrents KC (1987) The influence of shelter availability on recruitment and early juvenile survivorship of Lythrypnus dalli Gilbert (Pisces: Gobiidae). J Exp Mar Biol Ecol 107:45-59

Estabrook CB, Estabrook GF (1989) ACTUS: a solution to the problem of small samples in the analysis of two-way contingency tables. Hist Methods 22:5-8

Faria C, Almada V (2001) Microhabitat segregation in three rocky intertidal fish species in Portugal: does it reflect interspecific competition? J Fish Biol, in press

Faria C, Almada VC, Gonçalves EJ (1996) Juvenile recruitment, growth and maturation of Lipophrys pholis (Pisces: Blenniidae), from the west coast of Portugal. J Fish Biol 49:727-730

Faria C, Almada VC, Gonçalves EJ, Gil MF, Baptista C, Carreiro H (1998a) Notes on the social behaviour of Gobius cobitis (Pisces, Gobiidae). Acta Ethol 1:49-56

Faria C, Almada V, Nunes MC (1998b) Patterns of agonistic behaviour, shelter occupation and habitat preference in juvenile Lipophrys pholis, Coryphoblennius galerita and Gobius cobitis. J Fish Biol 53:1263-1273

Fishelson L (1963) Observations on littoral fishes of Israel I. Behaviour of Blennius pavo Risso (Teleostei, Blenniidae). Isr J Zool 12:67-80

Fives JM (1980) Littoral and benthic investigations on the west coast of Ireland XI. The biology of Montagu's blenny, Coryphoblennius galerita L. (Pisces), on the Connemara coast. Proc R Ir Acad B 80:63-79

Gibson RN (1967) Experiments on the tidal rhythm of Blennius pholis. J Mar Biol Assoc UK 47:97-111

Gibson RN (1968) The agonistic behaviour of juvenile Blennius pholis L. (Teleostei). Behaviour 30:192-217

Gibson RN (1969) The biology and behaviour of litoral fishes. Oceanogr Mar Biol Annu Rev 7:367-410

Gibson RN (1970) The tidal rhythm of activity of Coryphoblennius galerita (L.) Teleostei, Blenniidae). Anim Behav 18:539-543

Gibson RN (1971) Factors affecting the tidal rhythm of activity of Blennius pholis L. (Teleostei). Anim Behav 19:336-343 
Gibson RN (1972) The vertical distribution and feeding relationships of intertidal fish on the Atlantic coast of France. J Anim Ecol 41:189-207

Gibson RN (1978) Lunar and tidal rhythms in fishes. In: Thorpe JE (ed) Rhythmic activities in fishes. Academic Press, London, pp 201-213

Gibson RN (1982) Recent studies on the biology of intertidal fishes. Oceanogr Mar Biol Annu Rev 20:363-414

Gibson RN (1986) Intertidal teleosts: life in a fluctuating environment. In: Pitcher TJ (ed) The behaviour of teleost fishes. Croom Helm, London, pp 388-408

Gibson RN (1988) Patterns of movement in intertidal fishes. In: Chelazzi G, Vannini M (eds) Behavioural adaptations to intertidal life. Plenum Press, New York, pp 55-63

Gibson RN (1999) Movement and homing in intertidal fishes. In: Horn MH, Martin KLM, Chotkowski MA (eds) Intertidal fishes: life in two worlds. Academic Press, San Diego, pp 97-125

Gonçalves EJ, Almada VC (1998) A comparative study of territoriality in intertidal and subtidal blennioids (Teleostei, Blennioidei). Environ Biol Fish 51:257-264

Gonçalves EJ, Almada VC, Almeida SP, Gonçalves DM, Repas M, Simões N (1996) Observations on the agonistic behaviour of Lepadogaster lepadogaster purpurea (Pisces: Gobiesocidae). J Fish Biol 49:367-369

Grossman GD (1980) Food, fights and burrows: the adaptive significance of intraspecific aggression in the Bay Goby (Pisces: Gobiidae). Oecologia 45:261-266

Guitel F (1893) Observations sur les moeurs de trois blennidés Clinus argentatus, Blennius montagui et Blennius sphinx. Arch Zool Exp Géneral (3éme série) 1:325-384
Hartley PH (1949) Blennies and the ecology of littoral fishes. Rep Challenger Soc 31:1-19

Koppel VH (1988) Habitat selection and space partitioning among two Mediterranean blenniid species. Mar Ecol 9:329-346

Kotrschal K (1988) Blennies and endolithic bivalves: differential utilization of shelter in Adriatic Blenniidae (Pisces: Teleostei). PSZNI Mar Ecol 9:253-269

Mayr M, Berger A (1992) Territoriality and microhabitat selection in two intertidal New Zealand fish. J. Fish Biol 40:243-256

Phillips RR (1977) Behavioral field study of the Hawaiian rockskipper, Istiblennius zebra (Teleostei, Blenniidae) I. Ethogram. Z Tierpsychol 43:1-22

Qasim SZ (1956) The spawning habits and embryonic development of the shanny (Blennius pholis). Proc Zool Soc Lond 127:79-93

Qasim SZ (1957) The biology of Blennius pholis L. (Teleostei). Proc Zool Soc Lond 128:161-208

Santos RS (1985) Estrutura e função dos territórios em machos parentais de Blennius sanguinolentus Pallas (Pisces: Blenniidae). Mem Museu Mar, Série Zool 3(29):1-46

Santos RS (1986) Capacidade de retorno à área vital, padrão de dispersão e organização social em Blennius sanguinolentus Pallas (Pisces: Blenniidae) durante a época de reprodução. Psicologia 5(1):121-131

Wirtz P (1978) The behaviour of the Mediterranean Tripterygion species (Pisces, Blennioidei). Z Tierpsychol 48:142-174

Zander CD (1986) Bleniidae. In: Whitehead PJP, Bauchout M-L, Hureau L-C, Nielsen J, Tortonese E (eds) Fishes of the northeastern Atlantic and the Mediterranean, vol 3. UNESCO, Paris, pp 1096-1112 